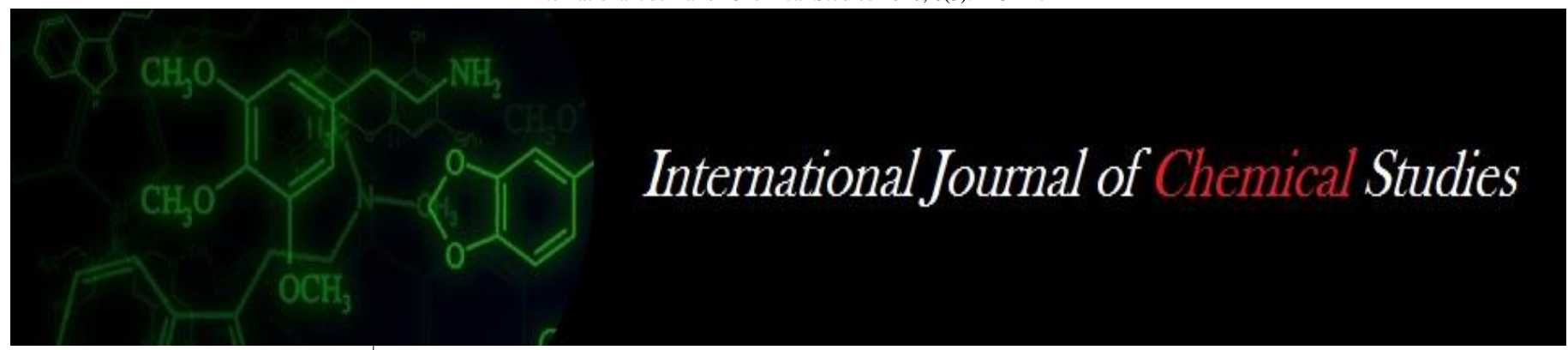

P-ISSN: 2349-8528

E-ISSN: 2321-4902

www.chemijournal.com

IJCS 2020; 8(3): 443-447

(C) 2020 IJCS

Received: 19-03-2020

Accepted: 20-04-2020

\section{E Naveena}

PG Research Scholar,

Department of Vegetable Science Horticultural College and

Research Institute, Tamil Nadu Agricultural University,

Periyakulam, Theni, Tamil

Nadu, India

\section{GJ Janavi}

Professor and Head, Department of Vegetable Science,

Horticultural college and

Research Institute, Tamil Nadu

Agricultural University,

Periyakulam, Tamil Nadu, India

T Arumugam

Dean (Horticulture),

Horticultural College and

Research Institute, Tamil Nadu

Agricultural University,

Periyakulam, Tamil Nadu, India

\section{T Anitha}

Assistant Professor, Department of Post-Harvest Technology,

Horticultural college and

Research Institute, Tamil Nadu

Agricultural University,

Periyakulam, Tamil Nadu, India

Corresponding Author:

E Naveena

PG Research Scholar,

Department of Vegetable Science Horticultural College and

Research Institute, Tamil Nadu

Agricultural University,

Periyakulam, Theni, Tamil

Nadu, India

\section{Estimation of nutritive composition of Sauropus androgynus (Multivitamin plant) at different growth stages and position of leaves}

\author{
E Naveena, GJ Janavi, T Arumugam and T Anitha
}

DOI: https://doi.org/10.22271/chemi.2020.v8.i3e.9251

\begin{abstract}
A study was designed to estimate the nutritive composition of Chekkurmanis (Katuk) leaves on two different growth stages viz., $60 \& 120$ days after planting and two different positions viz., terminal and basal whorls in plants. Utilization of green leafy vegetables differs from leaves of annuals and shrubs to leaves of trees. Katuk leaves rich in vitamins and minerals are known as protective food. The results of the study showed that Vitamin C, Protein, Calcium, Carbohydrate contents increased with the growth stages from 60 to 120 days. In contrast, Vitamin A content decreased as the plant approached 120 days. There is a significant difference in nutritive value from 60 to 120 days. Vitamin A was observed to be significantly high $(4.11 \mathrm{mg} / 100 \mathrm{~g})$ in terminal whorl at 60 days after planting compared to $3.01 \mathrm{mg} / 100 \mathrm{~g}$ in the terminal whorl at 120 days. Higher Vitamin A $(5.12 \mathrm{mg} / 100 \mathrm{~g})$ was observed in basal whorl leaves at 60 days after planting, while Vitamin C (220.41 mg/100g), Protein $(4.99 \mathrm{~g} / 100 \mathrm{~g})$, Calcium $(4.16 \%)$, Carbohydrate $(9.83 \mathrm{~g} / 100 \mathrm{~g})$ were observed in basal whorls on 120 days after planting. In conclusion, the basal whorls had more embedded nutritive value than the terminal whorl leaves. This study reveals that nutritive composition of Sauropus androgynus mainly depends on the growth stages and leaf position in the plant.
\end{abstract}

Keywords: Chekkurmanis leaves, nutritive analysis, growth stages and position (terminal or basal whorl) of leaves

\section{Introduction}

Chekkurmanis (Sauropus androgynus L.), the vernacular names of the crop are Katuk or Sweet leaf bush, belongs to the family Euphorbiaceae, is a shrubby glabrous perennial green leafy vegetable, extensively grown in warm humid tropics with ample rainfall. The crop is native of Indoburma region, later introduced to India from Malaya. It is widely distributed in Sikkim, Himalaya, Khasi, Abour and Arka hills, Western Ghats of Kerala. The plant is also cultivated in Australia, as it is nutritious, most prolific, high yielding with appetizing green leaves. Katuk is mainly propagated through semi hardwood cuttings of $20-30 \mathrm{~cm}$ length stem. The tender leaves and succulent shoots are used for cooking. In India, it is commonly known as Multivitamin or Multi green plant, because of its rich nutritive value, containing large amount of essential mineral elements, with high level of Vitamin A, Vitamin B, Thiamine (B1), Riboflavin (B2), Vitamin C, Carbohydrate, Calcium, Potassium, Phosphorous, Iron and Dietary Protein. Due to presence of antioxidants in the leaves, is utilized for treating many diseases viz., diabetics, cancer, allergy, microbial infection, cholesterol and swelling as reported by ${ }^{[29]}$ Paul and Beena Anto (2011). In India, anciently Katuk leaves were used to improve the eyesight, to cure skin diseases, urinary problems, cardiovascular problems, relieves internal fever and several other illness as stated by ${ }^{[25]}$ Ong (2003). Mineral deficiency and other related diseases can be overcome by intake of leafy vegetables in recommended quantities, as an appropriate amount of vitamins, minerals and phytochemicals are necessary for normal functioning of human metabolic processes. To understand the nutritive composition of Chekkurmanis at different growth stages and position of leaves, a study has been taken up at the Horticultural College and Research Institute, Periyakulam during 2019-2020.

\section{Materials and methods}

The healthy and disease-free rooted cuttings of Sauropus androgynus collected from Orchard, Agricultural College and Research Institute, Tamil Nadu Agricultural University (TNAU), 
Madurai, Tamil Nadu, were used as planting materials for the present study. Field trial was taken up at Horticultural College and Research Institute, Periyakulam. The experiment was conducted at Field No. 26 of Western Block Farm, Department of Vegetable Science, Horticultural College and Research Institute, Periyakulam, which is located at $80^{\circ}$ East longitude, $11^{\circ}$ North latitude, at an altitude of $300 \mathrm{M}$ above Mean Sea Level. The nature of soil in the experimental site was sandy loam. Chekkurmanis leaf samples were collected from terminal and basal whorls of the plants at 60 and 120 days after planting, to assess the nutritive composition of young (terminal whorls) and matured (basal whorls) leaves. The leaves were washed with tap water to remove adhering sand, dust and other contaminants on the surface. Fresh leaf samples were used for analyzing vitamins, carbohydrate and protein, while the leaf samples dried in hot air oven at $60^{\circ} \mathrm{C}$ for six hours were used for calcium analysis. All the analyses were carried out in three replicates.

\section{Estimation of Vitamin A}

The vitamin A was estimated by weighing $500 \mathrm{mg}$ of fresh leaf sample from terminal and basal whorl of leaves separately and macerated with $10.0 \mathrm{ml}$ of $80 \%$ acetone. The extract was centrifuged at $25000 \mathrm{rpm}$ for $10 \mathrm{mins}$. Supernatant was collected and made up to a volume of 20.0 $\mathrm{ml}$ in a volumetric flask. Finally, the values of extract were read in spectrophotometer at $510 \mathrm{~nm}$ and $480 \mathrm{~nm}$ as described by ${ }^{[17]}$ Jensen (1978) and the values are expressed in milligram per 100 gram.

Amount of Vit A in $100 \mathrm{~g}$ leaf sample

$$
=\frac{(7.6 \times 0 D @ 480 \mathrm{~nm})-(1.49 \times 0 D @ 510 \mathrm{~nm}) \times \mathrm{V}}{1000 \times \mathrm{W}}
$$

Where,

Weight $(\mathrm{g})$ of sample taken $=\mathrm{W}$

Volume $(\mathrm{ml})$ of supernatant $=\mathrm{V}$

\section{Estimation of Vitamin C}

The vitamin $\mathrm{C}$ content of the fresh leaves from the terminal and basal whorls were estimated separately by titrimetric method described by ${ }^{[13]}$ Harris and Ray (1935) and the values recorded as milligram per 100 gram. Leaves $(500 \mathrm{mg})$ from each sample were homogenized with $100 \mathrm{ml}$ of $4 \%$ oxalic acid and centrifuged at $2000 \mathrm{rpm}$ for 15 minutes. Then $5.0 \mathrm{ml}$ of supernatant solution was pipetted out and $10.0 \mathrm{ml}$ of $4 \%$ oxalic acid was added in porcelain basin. Finally titrated against dye solution.

Amount of ascorbic acid in $100 \mathrm{~g}$ leaf sample

$$
=\frac{0.5 \mathrm{mg}}{\mathrm{V} 1} \times \frac{\mathrm{V} 2}{15 \mathrm{ml}} \times \frac{100 \mathrm{ml}}{\mathrm{w}} \times 100
$$

Where,

Weight $(\mathrm{g})$ of sample taken $=\mathrm{W}$

Volume $(\mathrm{ml})$ of dye consumed by working standard $=\mathrm{V}_{1}$

Volume (ml) of dye consumed by sample $=V_{2}$

\section{Estimation of Carbohydrate}

The carbohydrate content of fresh leaves from terminal and basal whorls were analyzed separately by anthrone method suggested by ${ }^{[15]}$ Hodge and Hofreiter (1962) and the values are expressed in gram per 100 gram. 500mg of leaf sample was macerated with $80 \%$ hot ethanol, centrifuged at $2500 \mathrm{rpm}$ for 20 minutes and the residue was collected. Again washing was done with $80 \%$ hot ethanol till the anthrone reagent gives colourless solution. The residue was dried in water bath. Then $5.0 \mathrm{ml}$ of distilled water and $6.5 \mathrm{ml}$ of $52 \%$ per chloric acid were added. The extract was kept at $0^{\circ} \mathrm{C}$ for fifteen minutes. After centrifugation at $2500 \mathrm{rpm}$, the supernatant was collected. Extraction was repeated two to three times by using per chloric acid, centrifuged and the supernatants were pooled. The volume of each sample was made up to $100 \mathrm{ml}$ and used as test solution. $0.1 \mathrm{ml}$ of test solution was drawn and made up to $1.0 \mathrm{ml}$ using distilled water. $4.0 \mathrm{ml}$ of anthrone reagent was added and mixed thoroughly and kept in water bath for 8 minutes. Then the samples were cooled rapidly and read in spectrophotometer at $630 \mathrm{~nm}$ against the blank.

Amount of carbohydrate in $100 \mathrm{~g}$ leaf sample

$$
=\frac{\text { Graph value }}{\text { volume of test soln. }} \times \frac{\text { total volume of extract }}{\text { weight of sample }(\mathrm{g})} \times 100
$$

\section{Estimation of Protein}

The protein content of fresh leaves from terminal and basal whorls were analyzed separately by Biuret method as per [20] Layne (1957) and the results are expressed as gram per 100 gram. Leaves $(1.0 \mathrm{~g})$ from each sample was macerated with $10.0 \mathrm{ml}$ phosphate buffer, centrifuged at $1500 \mathrm{rpm}$ and then supernatant was collected. Extraction was repeated twice, supernatants were pooled and the volume was made up to 100 $\mathrm{ml}$ with phosphate buffer. Test solution $(0.5 \mathrm{ml})$ was pipetted out and volume made up to $1.0 \mathrm{ml}$ using distilled water. 4.0 $\mathrm{ml}$ biuret reagent was added, mixed thoroughly and incubated for 30 minutes at room temperature. The samples were read in spectrophotometer at $550 \mathrm{~nm}$ against the blank. Amount of protein in $100 \mathrm{~g}$ leaf sample

$$
=\frac{\text { Graph value }}{\text { volume of test soln. }} \times \frac{\text { total volume of extract }}{\text { weight of sample }(\mathrm{g})} \times 100
$$

\section{Estimation of Calcium}

The versenate method was used for estimation of calcium content in leaf samples. $0.5 \mathrm{~g}$ of dried leaf sample from terminal and basal whorl of leaves were taken separately in conical flask and $5.0 \mathrm{ml}$ of triple acid extract pipetted out into conical flask. Then kept in sand bath for 5.0 hours. After that $10 \%$ of sodium hydroxide $(\mathrm{NaOH})$ was added drop by drop to neutralize the acidity and another $5.0 \mathrm{ml}$ was added to maintain the $\mathrm{pH}$ at 12 . Then small quantity of murexide indicator was added and finally titrated against $0.02 \mathrm{~N}$ EDTA. The color change of violet from pinkish red was observed as suggested by ${ }^{[16]}$ Jackson (1973) and the values are expressed in percentage.

Percentage of Calcium in leaf sample

$$
=0.0004 \times \mathrm{B} \times \frac{\mathrm{V}}{5} \times \frac{100}{\mathrm{~W}} \times \frac{100}{(100-\mathrm{M})}
$$

Where,

Weight $(\mathrm{g})$ of sample taken $=\mathrm{W}$

Volume $(\mathrm{ml})$ of triple acid extract prepared $=\mathrm{V}$

Volume $(\mathrm{ml})$ of $0.02 \mathrm{~N}$ EDTA used for Calcium $=\mathrm{B}$

Moisture content $(\%)$ of the sample $=\mathrm{M}$

\section{Statistical analysis}

All the analyses were performed in triplicate and Analysis of variance (ANOVA) was carried out using statistical package 
WINDOWSTAT to evaluate variation between two levels of growth stage and leaf position of the plant.

\section{Result and discussion}

Table 1 represents the nutritive composition of terminal and basal whorls of Chekkurmanis leaves at two different growth stages viz., 60 and 120 days after planting and two positions in plants.

\section{Vitamin A}

The fresh leaves from terminal and basal whorl of Sauropus androgynus contained $4.11 \mathrm{mg} / 100 \mathrm{~g}$ and $5.12 \mathrm{mg} / 100 \mathrm{~g}$ Vitamin A respectively on 60 days, while $3.01 \mathrm{mg} / 100 \mathrm{~g}$ and $4.26 \mathrm{mg} / 100 \mathrm{~g}$ on 120 days. There existed significant difference $(P<0.05)$ in Vitamin A content in terminal and basal whorl leaves on $60 \& 120$ days. High Vitamin A content was found in basal whorl leaves on 60 days compared to terminal leaves on 120 days. This trend of Vitamin A content in Chekkurmanis leaves is analogous with results reported by [27] Padmavathi and Rao (1990) and less than the values reported by ${ }^{[10]}$ Devi et al. (2007). This content considerably reduced with later growth stage of the plant. This ensures the fact that Vitamin A is redistributed to every organ of plant as reported by ${ }^{[14]}$ Hocmuth et al. (2004). It is essential for effective functioning of visual system, reproduction, immune system, growth and development as stated by ${ }^{[33]}$ Sommer and WHO (1995).

In the present study, Vitamin A content of Chekkurmanis decreased when the plant were in advanced growth stage. Similar aspect was identified in $C$. argentea by ${ }^{[3]}$ Adegbaju $e t$ al. (2019) and ${ }^{[7]}$ Biesiada et al. (2007) for Leek, Zucchini and Kohlrabi. The values obtained from this study shows higher Vitamin A than Amaranthus digitata, Hibiscus sabdariffa and Vigna unguiculata as noticed by ${ }^{[28]}$ Patricia et al. (2014) and moringa leaves by ${ }^{[1]}$ Abbas et al. (2018).

Table 1: Nutritive composition of terminal and basal leaves of Chekkurmanis leaves

\begin{tabular}{|c|c|c|c|c|c|c|}
\hline Days after planting (DAP) & Position of leaf & Vitamin A (mg/100g) & Vitamin C (mg/100g) & Carbohydrate (g/100g) & Protein (g/100g) & Calcium (\%) \\
\hline \multirow{2}{*}{60 DAP } & Terminal whorl & $4.11^{\mathrm{b}}$ & $112.26^{\mathrm{b}}$ & $5.71^{\mathrm{b}}$ & $2.63^{\mathrm{b}}$ & $1.69^{\mathrm{b}}$ \\
\cline { 2 - 7 } & Basal whorl & $5.12^{\mathrm{a}}$ & $123.33^{\mathrm{a}}$ & $6.20^{\mathrm{a}}$ & $3.04^{\mathrm{a}}$ & $2.08^{\mathrm{a}}$ \\
\hline \multirow{2}{*}{$120 \mathrm{DAP}$} & Terminal whorl & $3.01^{\mathrm{b}}$ & $199.30^{\mathrm{b}}$ & $8.81^{\mathrm{b}}$ & $4.25^{\mathrm{b}}$ & $2.94^{\mathrm{b}}$ \\
\cline { 2 - 7 } & Basal whorl & $4.26^{\mathrm{a}}$ & $220.41^{\mathrm{a}}$ & $9.83^{\mathrm{a}}$ & $4.99^{\mathrm{a}}$ & $4.16^{\mathrm{a}}$ \\
\hline \multicolumn{2}{|c|}{ SEd } & 0.114 & 4.492 & 0.139 & 0.101 & 0.056 \\
\hline \multicolumn{2}{|c|}{ CD $(P<0.05)$} & 0.280 & 10.992 & 0.342 & 0.248 & 0.137 \\
\hline
\end{tabular}

Mean values carrying superscript letters represent significant difference at $P<0.05$

\section{Vitamin C}

The Vitamin C content in terminal and basal whorl of fresh Chekkurmanis leaves were $112.26 \mathrm{mg} / 100 \mathrm{~g}$ and 123.33 $\mathrm{mg} / 100 \mathrm{~g}$ respectively on 60 days, while on 120 days after planting the content were $199.30 \mathrm{mg} / 100 \mathrm{~g}$ and 220.41 $\mathrm{mg} / 100 \mathrm{~g}$ respectively. The Vitamin $\mathrm{C}$ content raised considerably with age. There existed significant difference $(P$ $<0.05)$ in Vitamin $\mathrm{C}$ content in terminal and basal whorl leaves on $60 \& 120$ days. High Vitamin C (220.41 mg/100g) content was noted in basal whorl leaves on 120 days and lesser value $(92.26 \mathrm{mg} / 100 \mathrm{~g})$ in terminal leaves on 60 days. Similar trend was observed in Telifairia occidentalis by ${ }^{[18]}$ Platel and Srinivasan (2017) and ${ }^{[5]}$ Musa et al. (2012). The previous study in Chekkurmanis by ${ }^{\text {[2] }}$ Padmavathi and Rao (1990) and ${ }^{[31]}$ Singh et al. (2011) reported that vitamin C content was $244.00 \mathrm{mg} / 100 \mathrm{~g}$ and $314.30 \mathrm{mg} / 100 \mathrm{~g}$ respectively in terminal and basal whorls, which was higher than this study result. According to ${ }^{[21]}$ Lee and Kadar (2000), the maturity of leaves is a major factor that determines the compositional value of vegetables. Further ${ }^{[19]}$ Korus (2010) observed that Vitamin $\mathrm{C}$ content depends on degree of plant maturity and variety. In this study, Vitamin $\mathrm{C}$ attained the maximum value of $220.41 \mathrm{mg} / 100 \mathrm{~g}$ in basal whorl leaves on 120 days. It is very high when compared with Amaranthus digitata $(70.00 \mathrm{mg} / 100 \mathrm{~g})$ and Hibiscus sabdariffa $(30.00$ $\mathrm{mg} / 100 \mathrm{~g}$ ) as reported by ${ }^{[28]}$ Patricia et al. (2010) and Moringa oleifera $(0.56 \mathrm{mg} / 100 \mathrm{ml})$ as reported by ${ }^{[2]}$ Achikanu et al. (2013).

Vitamin C supports synthesis of hormone, iron absorption and collagen, which is extensively used in cosmetics and pharmaceuticals. It acts as water soluble antioxidant, which plays a major role in free radical scavenging activity and activates immune system ${ }^{[22]}$ (Locato et al., 2013).

\section{Carbohydrate}

The carbohydrate value observed in terminal and basal whorl of fresh leaves were $5.71 \mathrm{~g} / 100 \mathrm{~g}$ and $6.20 \mathrm{~g} / 100 \mathrm{~g}$ respectively on 60 days, while $8.81 \mathrm{~g} / 100 \mathrm{~g}$ and $9.8 \mathrm{~g} / 100 \mathrm{~g}$ respectively on 120 days. Carbohydrate content was high $(9.83 \mathrm{~g} / 100 \mathrm{~g})$ in basal leaves on 120 days and low $(5.71 \mathrm{~g} / 100 \mathrm{~g})$ in terminal leaves on 60 days. The basal whorl leaves consisted of more carbohydrate $(6.20 \mathrm{~g} / 100 \mathrm{~g} \& 9.8 \mathrm{~g} / 100 \mathrm{~g})$ when compared with terminal whorl leaves $(5.71 \mathrm{~g} / 100 \mathrm{~g} \& 8.81 \mathrm{~g} / 100 \mathrm{~g})$ on 60 and 120 days. There existed significant difference $(P<0.05)$ in carbohydrate content on the terminal and basal whorl leaves on $60 \& 120$ days. The content also significantly increased which respect to the maturation of the plants and this finding is in line with the findings of ${ }^{[3]}$ Adegbaju et al. (2019). The amount of carbohydrate observed in this study was identical with earlier research reported in Sauropus androgynus by [9] Chakraborty et al. (2019), but lower than as reported by [10] Devi et al. (2007). Carbohydrate is a fundamental element for normal functioning of human body. Ingestion of carbohydrate enriched leaves adds energy level to diet by providing favourable nutrition. Amount of carbohydrate in basal leaves of katuk is higher than $T$. occidentalis but lower than $C$. aconitifolius as indicated by ${ }^{[26]}$ Otitoju et al. (2014) and equal to the Senna occidentalis, Solanum nodiflorum, Physalis viscose by ${ }^{[24]}$ Odhav et al. (2007), moringa leaves as observed by ${ }^{[1]}$ Abbas et al. (2018).

\section{Protein}

Fresh leaves of terminal and basal whorl leaves of Chekkurmanis contained protein content in the range of 2.63 $\mathrm{g} / 100 \mathrm{~g} \& 3.04 \mathrm{~g} / 100 \mathrm{~g}$ respectively at 60 days, while it was $4.25 \mathrm{~g} / 100 \mathrm{~g} \& 4.99 \mathrm{~g} / 100 \mathrm{~g}$ respectively at 120 days. There existed significant difference $(P<0.05)$ in protein content on the terminal and basal whorl leaves on $60 \& 120$ days. Previously ${ }^{[32]}$ Singh et al. (2011) published the literature and reported that protein content of Chekkurmanis leaves were $5.25 \mathrm{~g} / 100 \mathrm{~g}$. From the result of this study, the protein content of Sauropus androgynus increased with age of the plant. 
According to ${ }^{[6]}$ Bamishayie (2011), the protein content of moringa leaves was moderately low at initial stage $(27.61 \%)$ and finally reached higher values on later stage $(28.08 \%)$. The highest protein content $(4.99 \mathrm{~g} / 100 \mathrm{~g})$ was recorded in basal whorl of the plant on 120 days after planting and the lowest content $(2.63 \mathrm{~g} / 100 \mathrm{~g})$ was recorded on terminal whorl of the plant 60 days after planting. The protein values found in basal leaves of Chekkurmanis on 120 days after planting were higher than Petroselinum crispum (2.97 g/100g), Anethum graveolens (3.46 g/100g), Lactuca sativa (1.62 g/100g), Brassica oleraceae $(1.21 \mathrm{~g} / 100 \mathrm{~g})$ as reported by ${ }^{[8]}$ Caunii et al. (2010), but lower than Moringa oleifera leaves (6.7 $\mathrm{g} / 100 \mathrm{~g}$ ) as reported by ${ }^{[11]}$ Gopala Krishnan et al. (2016). Therefore, Sauropus androgynus has the potential to serve as a very good source of protein for the reduction of protein malnutrition. It also acts as neurotransmitter and carries the oxygen in blood. Deficiency of protein causes malnutrition diseases viz., kwashiorkor and marasmus and results in stunted growth. It is also useful for immune function, creation of enzymes and hormones and maintains fluid balance in the body.

\section{Calcium}

Calcium content of dried leaf samples collected from both terminal and basal whorl of leaves was in the range of $1.69 \%$ and $2.08 \%$ respectively on 60 days, whereas it was $2.94 \%$ and $4.16 \%$ respectively on 120 days. There existed significant difference $(P<0.05)$ in calcium content in the terminal and basal whorl leaves on $60 \& 120$ days after planting. Calcium percentage obtained in this study is more $(4.16 \%)$ than that $(0.7 \%)$ as stated by ${ }^{[27]}$ Padmavathi and Rao (1990). In the present study, the highest calcium content observed in basal leaves at 120 days was $4.16 \%$. This finding is in agreement with ${ }^{[23]}$ Modi (2007), who observed more calcium content in long day interval than short day interval in amaranthus plant. In contrast, the lowest calcium content of $1.69 \%$ was recorded in the terminal leaves on 60 days. The highest calcium content in basal leaves might be due to immobility (non-translocation) of calcium in the plant. This concept is in agreement with the authors ${ }^{[35]}$ Taiz \& Zeiger (2002) and ${ }^{[14]}$ Hochmuth et al. (2004).

When the plants approach maturity, the nutrient content (calcium) in the leaves gets increased. This concept is in agreement with the values reported by ${ }^{[18]}$ Platel and Srinivasan (2017) for Chekkurmanis crop and similar trend with age of plant was observed in tender and mature stages of Celosia argentea plant by ${ }^{[3]}$ Adediran et al. (2015). Calcium plays an important role in nervous system, cell signaling and muscle contraction. It also helps to maintain healthy teeth and bones. Calcium is also utilized by cells for transferring ions and triggers several enzymes secretion in human body by ${ }^{[31]}$ Sadler (2011). The values found in this study are higher than some of underutilized green leafy vegetables such as Digera arvensis (0.50\%), Amaranthus tricolor (0.23\%) and Cucurbita maxima $(0.30 \%)$ as reported by ${ }^{[12]}$ Gupta et al. (2004), Hibiscus sabdariffa (0.4\%) and Ipomea aquatica (0.09\%) by ${ }^{[32]}$ Singh et al. (2011), Alternenthra sessilis (2.0 $\%)$ and Celosia argentea $(2.03 \%)$ as reported by ${ }^{[30]}$ Rekha Sinha (2018) and Moringa oleifera $(1.14 \%)$ by ${ }^{[34]}$ Srivastava et al. (2018).

\section{Conclusion}

The results of the study indicate that Sauropus androgynus is an excellent source of Vitamin A \& C, Carbohydrate, Protein and Calcium than any other leafy vegetables. Further, the green leafy vegetables are fine source of vitamins, minerals and other minor elements. The study reveals that basal whorl of leaves consist of more nutrient content than terminal whorl leaves and there existed significant difference between the nutritional constituents in leaves upon growth of the plant.

\section{References}

1. Abbas RK, Elsharbasy FS, Fadlelmula AA. Nutritional Values of Moringa oleifera, Total Protein, Amino Acid, Vitamins, Minerals, Carbohydrates, Total Fat and Crude Fiber, under the Semi-Arid Conditions of Sudan. Journal of Microbial and Biochemical Technology. 2018; 10(2):56-58.

2. Achikanu CE, Eze-Steven PE, Ude CM, Ugwuokolie OC. Determination of the vitamin and mineral composition of common leafy vegetables in South Eastern Nigeria. International Journal of Current Microbiol. Appl. Sci. 2013; 2(11):347-353.

3. Adediran OA, Gana Z, Oladiran JA, Ibrahim H. Effect of age at harvest and leaf position on the yield and nutritional composition of Celosia argentea L. International Journal of Plant and Soil Science. 2015; 5(6):359-365.

4. Adegbaju OD, Otunola GA, Afolayan AJ. Proximate, mineral, vitamin and anti-nutrient content of Celosia argentea at three stages of maturity. South African Journal of Botany. 2019; 24:372-379.

5. Amanabo Musa, Emmanuel Ogbadoyi O. Effect of Plant Leaf Positions on Some Micronutrients, Anti-nutrients and Toxic Substances in Telfairia occidentalis at the vegetative phase. American Journal of Experimental Agriculture. 2012; 2(2):219-232.

6. Bamishaiye EI, Olayemi FF, Awagu EF, Bamshaiye OM. Proximate and phytochemical composition of Moringa oleifera leaves at three stages of maturation. Advance Journal of Food Science and Technology. 2011; 3(4):233-237.

7. Biesiada A, Kołota E, Adamczewska-sowińska K. The effect of maturity stage on nutritional value of leek, zucchini and kohlrabi. Veg. Crops Res. 2007; 66:39-45.

8. Caunii A, Cuciureanu R, Zakar AM, Tonea E, Giuchici C. Chemical composition of common leafy vegetables. Studia Universitatis VasileGoldis Arad. Seria Stiintele Vietii (Life Sciences Series). 2010; 20(2):45-48.

9. Chakraborty Ivi, Riadh Ilahy, Balaji Vikram, Arghya Mani. Recent Trends \& Advances in Food Science\& Post Harvest Technology. Edn I, Satish serial publishing house, Delhi. 2019; I:207-218.

10. Devi NS, Sadhan Kumar PG, Peter KV, Indira V. Indigenous leaf vegetables for administering vitamin A and minerals. In International Conference on Indigenous Vegetables and Legumes. Prospectus for Fighting Poverty, Hunger and Malnutrition. Acta Hort. 2007; 752:367-372.

11. Gopalakrishnan L, Doriya K, Santhosh Kumar D. Moringa oleifera: A review on nutritive importance and its medicinal application. Food science and human wellness. 2016; 5(2):49-56.

12. Gupta S, Jyothi Lakshmi A, Manjunath MN, Prakash J. Analysis of nutrient and antinutrient content of underutilized green leafy vegetables. LWT-Food Science and Technology. 2005; 38(4):339-345.

13. Harris LJ, Ray SN. Determination of plasma ascorbic acid by 2, 6-dichlorophenol indophenol titration. Lancet. $1935 ; 1(7): 1$. 
14. Hocmuth G, Maynard D, Vavrina C, Hanlon E, Simonne E. Plant tissue analysis and interpretation for vegetable crops in Florida. University of Florida's Institute of Food and Agricultural Sciences (UF/IFAS), 2004, 1-79.

15. Hodge JE, Hofreiter BT. In: Methods in Carbohydrate Chemistry, Academic Press, New York, 1962.

16. Jackson ML. Soil Chemical Analysis. Prentice Hall of India Pvt. Ltd. New Delhi, 1973, 183-204.

17. Jensen A. Chlorophylls and carotenoids. Handbook of phytological Methods, Cambridge Univ. Press, London, 1978, 59-70.

18. Kalpana Platel, Krishnapura Srinivasan. Nutritional Profile of Chekurmanis (Sauropus androgynus), A Less Explored Green Leafy Vegetable. Indian Journal of Nutrition and Dietetics. 2017; 54(3):244.

19. Korus A. Level of vitamin C, polyphenols and antioxidant andenzymatic Activity in three varieties of kale (Brassica oleracea L. var. acephala) at different stages of maturity. Int. J. Food Properties. 2010; 14:10691080.

20. Layne E. Methods Enzymol. Academic Press, New York $-3,1957,447-466$.

21. Lee SK, Kader AA. Preharvest and postharvest factors influencing vitamin C content of horticultural crops. Postharvest Biol. Technol. 2000; 20:207-220.

22. Locato V, Cimini S, DeGara L. Strategies to increase vitamin $\mathrm{C}$ in plants: from plant defense perspective to food biofortification. Front. Plant Sci. 2013; 4(152):1-12.

23. Modi AT. Growth temperature and plant age influence on nutritional quality of Amaranthus leaves and seed germination capacity. Water SA. 2007; 33(3):369-376.

24. Odhav B, Beekrum S, Akula US, Baijnath H. Preliminary assessment of nutritional value of traditional leafy vegetables in KwaZulu-Natal, South Africa. Journal of Food Composition and Analysis. 2007; 20(5):430-435.

25. Ong HC. Sayuran: Khasiat Makanan \& Ubatan, Utusan Publications and Distributors, Kuala Lumpur, Malaysia, 2003.

26. Otitoju GTO, Ene-Obong HN, Otitoju O. Macro and micro nutrient composition of some indigenous green leafy vegetables in south-east zone Nigeria. J Food Process Technol. 2014; 5(11):1-6.

27. Padmavathi P, Prabhakara Rao M. Nutritive value of Sauropus androgynus leaves. Plant Foods Hum Nutr. 1990; 40(2):107-13.

28. Patricia O, Zoue L, Megnanou RM, Doue R, Niamke S. Proximate composition and nutritive value of leafy vegetables consumed in Northern Cote d'Ivoire. European Scientific Journal. 2014; 10(6):212-227.

29. Paul M, Beena Anto K. Antibacterial activity of Sauropus androgynus (L.) Merr. Int. J Plant Sci. 2011; 6(1):189-192.

30. Rekha Sinha. Nutritional analysis of few selected wild edible leafy vegetables of tribal of Jharkhand, India. Int. J. Curr. Microbiol. App. Sci. 2018; 7(2):1323-1329.

31. Sadler TW. Langman's Medical Embryology. Wolters Kluwer Lippincott Williams \& Wilkins, Edn 11, Philadelphia, 2011.

32. Singh S, Singh DR, Salim KM, Srivastava A, Singh LB, Srivastava RC. Estimation of proximate composition, micronutrients and phytochemical compounds in traditional vegetables from Andaman and Nicobar Islands. International Journal of Food Sciences and Nutrition. 2011; 62(7):765-773.
33. Sommer A, World Health Organization. Vitamin a Deficiency and its Consequences: A Field Guide to Detection and Control. World Health Organization, Edn 3, Geneva, 1995.

34. Srivastava, Pan RS, Bhatt BP. Antioxidant and nutritional potential of some underutilized leafy vegetables consumed by tribals of Jharkhand, India. Current Science. 2018; 114(6):1222-1233.

35. Taiz L, Zeiger E. Plant physiology. Sinaeur Associates, Inc. Sunderland. Massachusetts. Edn 3, 2002, 370-372. 